\title{
A VÁROSTERVEZÉS REGIONÁLIS KERETEINEK KIALAKULÁSA ÉS FEJLŐDÉSE NAGY-BRITANNIÁBAN
}

\author{
(Evolvement and Developement of Regional Framework for Town \\ Planning in Britain)
}

\section{NAGY ERIKA}

A területi tervezéssel foglalkozó tanulmányokban, vitákban időről időre felvetödik a regionális szerepkörökkel rendelkezö megyei városok és a megyék, illetve régiók viszonya. A városhálózat ezen elemei a gazdasági fejlödés, az intézmények és a társadalmi szervezetek csomópontjai, ezért az utóbbi években készült területfejlesztési stratégiák egyik alapkérdése lehetőségeik, potenciáljaik kutatása. A konkrét fejlesztési lépések összehangolásához város és vidéke esetében azonban hiányoznak az intézményes keretek. Vannak példák olyan stratégiai tervekre (például Veszprém esetében) és általános rendezési tervekre (például Sopronban), ahol a környezö falvakkal közösen alakították ki elképzeléseiket a jövöbeni fejlödés fö irányairól. Gyakoriak azonban az olyan hírek, ahol egy-egy település úgy hozza meg saját közigazgatási területét érintő döntéseit, hogy az a szomszédok kárára válik. Egy regionális jelentőségü bevásárlóközpont felépitésének hatásai és jelentősége kétségtelenül túlnyúlik egyetlen város, vagy akár község határain. A regionális és várostervezés kapcsolatrendszere tehát nyitott kérdés. Ezért nem haszontalan olyan példák után kutatni, ahol már mủködő modellek léteznek, amelyek hibái és előnyös vonásai tanulságokkal szolgálnak a hazai szakemberek számára.

\section{Az elsö kísérletek a városi környezet átalakitására}

Nagy-Britannia lakossága tapasztalta meg legkorábban az európai országok közül a városok növekedésének negatív következményeit: 1801-ben a szigetország lakosságának kétharmada élt városokban, 1901-ben már négyötöde. A századfordulón négymilliós metropolisz, London, Manchester, Birmingham és Glasgow nőtte túl saját igazgatási határait, és hasonló folyamat zajlott KözépAngliában, a Fekete-vidék kisebb centrumaiban is. A gyors növekedés következményeként már az ipari forradalom kezdetén jelentkezett a túlzsúfoltság, a környezetszennyezés és a városi infrastruktúra kapacitásai is szüknek bizonyultak. A városi környezet és a közbiztonság romlása a múlt század közepén elinditotta az arisztokrácia mellett a középosztálybeliek kiáramlását a város peremére. A London szélén felépülö villák az ideális életforma megtestesítői voltak a korabeli Angliában nem csupán a tehetősek, hanem a társadalom egésze számára. A társadalmi reformerek és az épitészek, akiket a várostervezök előfutáraiként tartanak számon, a kertes családi ház és a vidéki(es) környezet megteremtésében látták a harmonikus 
társadalom megteremtésének alapfeltételét, $\mathrm{s}$ ez a brit tervezés sajátos alapelveként vált ismertté a kontinensen és azon túl.

Miközben a 19. századi brit városok népessége tovább duzzadt, a liberalizmus szellemében kormányzó brit politikusok óvakodtak minden olyan lépéstōl, amely a magántulajdont megsérthette. A slumok valóságát a vidéki idillhez legfeljebb távolról közelíthették a közegészségügyi és az ezzel szorosan összefüggö lakóházépitési szabályozásokkal. Mivel a helyi kormányzat hatáskörébe csupán az utak fenntartása, a csatornázás, a légszennyezés ellenōrzése, továbbá a tũzvédelmi építési szabályok betartatása tartoztak korábban, a városi életkörülmények javitása a helyi hatóságok (jogi) mozgásterének folyamatos növelését feltételezte. A lakosság romló egészségi állapotát és erkölcseit szoros összefüggésbe hozták a lakáskőrülményekkel, ezért olyan beavatkozások sorozata indult el, amelyek célja a spekulatív magánberuházások korlátozása volt. Ennek egyik csúcspontja az 1890-es lakástörvény, amely lehetővé tette a helyi kormányzat számára a nyomornegyedek lerombolását és bérházak építését a munkások számára. (Sutcliffe 1981)

$\mathrm{Az}$ urbanizáció problémakörének leszükítése a lakáskérdésre több okkal magyarázható. Ekkor még nem léteztek olyan iskolák, amelyek a városi környezet egészével foglalkoztak: az épitészek mellőzték a közlekedési hálózat fejlesztésének kérdését, a szociológia tudományának elöfutárai pedig ideológiai vitákba merültek. A helyi kormányzatok döntéshozói olyan tisztes, középosztálybeli polgárok közül kerültek ki, akik nem léphettek túl (tudás és információ hijản, továbbá neveltetetésüknél fogva) a részmegoldásokon, nem vállalkozhattak átfogó reformokra. (Knox 1987) Ezek megindítását lassította az is, hogy a népsürüség alacsonyabb volt a brit városokban, mint a kontinens többi országában, ami alapvetōen elfogadhatóvá tette a létező városszerkezetet az 1890-es évek végéig, megváltoztatása legfeljebb a slumok átalakitásával viszonylag kis területen volt elképzelhetô.

Az 1890-es évek több szempontból is alapvetô változást hoztak a várostervezés fejlödésében. A helyi hatóságok hivatalaiban többségbe kerültek a képzett szakemberek, a helyi döntéshozatalba pedig bejutottak az elsô munkások a választójog kiterjesztésének köszönhetően. A helyi kormányzat szintjén tehát kialakultak az átfogó reformok feltételei. Ennél is fontosabb azonban, hogy a tömegközlekedés fejlödésnek köszönhetöen (a villamos vasút, majd metró hálózatának folyamatos bövítésével) elérhetövé vált az áhított családi ház, vagy legalább sorházbeli lakás a munkások növekvő hányada számára. (Az utóbbihoz jelentösen hozzájárult az évtized gazdasági fellendülése és a bérek növekedése.)

Megkezdödött tehát a tömeges szuburbanizáció korszaka Nagy-Britanniában, ami megoldást kínált hosszú távon a városi környezet problémáira. A folyamat azonban egy sor új gondot is jelentett. Ezek közé tartozott a növekvő forgalom szervezésének szükségessége, illetve az úthálózat kapacitásának növelése, továbbá a város terjeszkedésének, az újonnan beépitett területeknek a megtervezése. Az utóbbi feltételeit az 1909-es várostervezési törvény volt hivatott megteremteni, amely a helyi kormányzat számára biztositotta a jogot az utcahálózat tervezésére, épitési szabályok bevezetésére a lakóterületeken és tartalékterületek fenntartására középületek és -terek számára. A törvény sokak számára kiábrándulást jelentett, mert az elsöbbséget adott a magántulajdonnak, hiszen nem tette lehetôvé átfogó terv 
megvalósítását a város egész perifériájára, és nem tísztázta az önkormányzatok területvásárlási jogait sem. (Hall 1993; Cherry 1974)

A város terjeszkedése felvetette egy új szakma (az 1950-es évektöl: tudományterület) elméleti és oktatási háttere megteremtésének igényét is. Az első várostervezési iskolákat Liverpoolban (1909) és Londonban (1914) hozták létre, amelyek a brit várostervezés fejlödésében napainkig meghatározó szerepet játszanak. Az egyetemi szintü képzés egyrészt olyan a szakembereket bocsátott ki, akik építészeti, mérnöki és geodéziai ismeretekkel is rendelkeztek. Másrészt képviselték a brit tervezés paradigmáját, amely a 20. században, Európában és azon túl is meghatározó szerepet játszott a tervezésben.

Az elmélet - vagy inkább - modell kidolgozója E. Howard, aki 1898-ban összegezte Észak-Amerikában ${ }^{1}$ és Európában szerzett gyakorlati tapasztalait, a kortársak elképzeléseit a szükséges társadalmi reformról az anarchistáktól a fábiánusokig, továbbá $H$. Spencer elképzelését a föld kisajátításáról és $A$. Marshall javaslatait London lakosságának dekoncentrációjára vonatkozóan. Howard tervei nem csupán a létezö városi környezet javítására vonatkoztak, hanem egy teljes, alternatív városrendszer megteremtésére. Ez kezdetben versenytársa volna a meglevő centrumoknak, majd az utóbbiak lassú elsorvadásával, új, a város és vidék harmóniáját megteremtő településszerkezet alakulna ki. A modell, bár a város gondjaira keresett megoldást, a sorvadó, évszázadok óta népességet vesztő falusiagrár térségeket sem hagyhatta figyelmen kívül. Sem ez utóbbiak helyzete, sem a város belsö nyomornegyedeinek körülményei nem javultak a városi népesség dekoncentrációja ellenére, ezért folyamodott Howard egy új utópiához.

$\mathrm{Az}$ olcsó mezőgazdasági területen felépített városrendszerek egyesítették magukban város és vidéke kedvezö vonásait. Az elöbbiek iparuk és szolgáltató intézményeik révén jövedelmet és kulturált életkörülményeket biztosítottak lakóiknak, lehetőséget a művelödésre, tanulásra, az egészség megóvására. A környezet minőségét e város határain belüli, kiterjedt zöld területek biztositották. A várost körülvevő mezőgazdasági területek nem csupán az agrárnépesség megélhetését biztosították, hanem külsỏ zöldövezetet is a városlakók számára. A városok mérete korlátozott, a modell szerint nem növekedhettek a környező vidék rovására. A növekvő igényeket újabb városok építésével elégítették volna ki.

Az új városok sejtekbe szerveződő egységek Howard elméletében: a központi, 58 ezer lakost számláló város körül térben egyenletesen hat, egyenként 32 ezer föt tömörítö kisebb városi település helyezkedne el (együttesen: the Social City). Egyik sem túl nagy ahhoz, hogy akadályozza helyi közösségek kialakulását, amelyek képesek önmaguk (és környékük) kormányzására. Ezek a kedvezö életfeltételeket kínáló városok a zsúfolt, egészségtelen nagyvárosi környezetböl toboroznák népességüket, amely végül az utóbbi hanyatlásához, a spekuláción meggazdagodó épitési vállalkozók szerepének csökkenéséhez vezet. (Howard 1994) Az utóbbiak helyét az új közösségek vennék át, melyek a város és környéke fejlödésének minden aspektusát felügyelnék. Ennek forrása a javak és jövedelmek újraelosztása a városi földtulajdonosok rovására és az új lakóközösségek javára.

Howard tehát, bár a város jobbításának szándéka vezérelte, végső soron utópista terület- és településfejlesztési modellt dolgozott ki. Ennek ellenére mégsem öt tekintik a brit területi tervezés atyjának. Az elképzelés gyakorlati következményei 
ugyanis szórványosak voltak 1946-ig. Egyetlen igazi, howard-i kertváros épült fel (Letchworth Garden City, 34 mérföldre Londontól), és csupán néhány kertvárosi jellegủ szuburbán lakónegyed (Hampstead Garden Suburb, London), elsősorban London környékén. A legnagyobb gondot a földterület megvásárlásához, illetve az építkezések elindításához szükséges töke elöteremtése jelentette. A beépítés minősége követte Howard elképzeléseit, de a tervek megmaradtak egy-egy város keretein belül.

\section{A regionális tervezés születése}

Ahhoz, hogy a brit tervezök a gyakorlatban is túllépjenek a városok közigazgatási határain, a két világháború között a nagyvárosok peremén zajló építkezések adtak lökést: a korszakban évente 375 ezer lakás épült. A helyi önkormányzatok, amelyek növekvö számban foglalkozattak képzett várostervezöket, aktív résztvevői voltak a folyamatnak: több mint egymillió lakást építettek, túlnyomórészt a városi perifériákon (London, Manchester, Liverpool, Glasgow). Ezek eredményei szuburbán lakónegyedek és szatellitvárosok voltak, a kontinens nyugati és középsö részéhez hasonlóan. Egy részük - a kisebbség - gondosan tervezett, tömegközlekedési kapcsolatokkal rendelkezö és zöld területekkel tüzdelt terület. Nagyobb részük azonban monoton, viszonylag sürü beépítésű (sorházak, zsebkendönyi hátsó kerttel), szolgáltatásokkal gyengén ellátott lakónegyed.

Szükség volt tehát a város terjeszkedésének ellenörzésére és tervezésére. Ez azonban jogi-igazgatási gondokat vetett fel, hiszen egyrészt a városi önkormányzatok tervezési jogköreinek bövítésére volt szükség (földvásárlás, átfogó tervek készítése, a magántulajdonosok érdekeinek korlátozásával), másrészt a helyi kormányzatokon túlnyúló tervek készítéséröl, s a megvalósitást irányitó, új igazgatási szervezetek létrehozásáról. Nem véletlen tehát, hogy a városnövekedés gondjait orvosolni hivatott regionális tervezés a két világháború között született meg Nagy-Britanniában.

A regionális tervezés elméleti alapjait $P$. Geddes teremtette meg, aki merített a francia emberföldrajzi iskola régió-értelmezéséből, módszereiböl (a természeti- és kultúrtáj egysége, mint a régiófogalom alapja; a régió tanulmányozása, feltérképezése a terv elkészítése előtt) és az anarchista hagyományokból (városok, régiók önálló és önként együttmüködő közösségeire épülö civilizáció). A szétterülö és összenövő városok - konurbációk - negatív vonásai és hatásai Geddes szerint kiküszöbölhetök a város és régiója fejlödésének együttes tervezésével. A folyamat emberibbé teszi a városokat (howard-i kertvárosok épitésével) és megakadályozza a vidék kizsákmányolását, illetve elnéptelenedését. ( $P$. Geddes 1915)

Geddes elképzelései keretbe foglalták a várostervezési elképzeléseket, irányzatokat. Hatása nem tágabb hazájában ${ }^{2}$, hanem az Egyesült Államokban jelentkezett elsőként. Ennek okai a magasabb jövedelmekben, a személyautók gyorsabb elterjedésében és ennek következtében a dekoncentrációs folyamatok nagyobb léptékében keresendök. Az 1922-23-ban alapitott Amerikai Regionális Tervezési Társaság (Regional Planning Association of America, RPAA) kapcsolatai szorosak voltak Geddes-szel, és az elsök között készitettek terveket regionális léptékben. Elképzeléseikben hangsúlyozták a természeti környezet megóvásának 
szükségességét, és meghatározták a nagyváros és vidéke viszonyát. A szervezet egyik alapítója, L. Mumford szerint a regionális tervezés feladata "nem egy-egy metropolisz vonzásterületének vizsgálata, hanem a népesség és a városi szolgáltatások optimális térbeli eloszlásának kutatása a természeti (éghajlati, talajés növény-) földrajzi, gazdasági és kulturális szempontból egységet alkotó régiókon belül. Az eloszlás közelitése az optimálishoz a tervezés feladata, hogy elösegitse és ösztönözze az alkotó tevékenységet és a fejlödést a térség egészében" ${ }^{3}$ A regionális tervezésnek kellett megteremtenie a kereteket az új, jobb társadalom számára az RPAA elképzelései szerint, míg a howard-i kertváros a tartalmat, az elérendő célt jelentette: a midennapi élet kellemes, falusias környezetének és a városi szolgáltatások kombinációját. (Hall 1993)

A szervezetben tömörülö mérnökök, építészek és társadalomtudósok erősen bírálták az elsö, New York-i régióra készült tervet (1928) annak mérsékelt célkitúzései miatt, amelyek út- és parképités, illetve az épitési szabályozás eszközeivel törekedtek egy hatékonyabb és kellemesebb városi környezet megteremtésére. T. Adams és munkatársai, a regionális terv készítöi az RPAA idealistáival szemben úgy vélték, hogy a régió térszerkezete már kialakult, azt csak szerény léptékủ beavatkozásokkal csupán módositani lehet. A hatékonyságot csökkentő centralizáció alternatívája szerintük nem a teljes decentralizáció, amelyet az RPAA támogatott, hanem a centralizációs folyamatok irányitása az új alközpontok felé. Mivel a regionális szintü tervezési-igazgatási szervezet gondolatát elutasították, a végrehajtás az egyes alrégiók tervezési tanácsai és magánvállalkozások együttmüködésén alapult.

A regionális tervezés szerepéröl és gyakorlatáról folytatott elméleti jellegü vita tükrözte Geddes gondolatainak ellentmondásosságát: mindkét oldal hivatkozott 1915-ben írott alapmüvére. ${ }^{4}$ Kétségtelenül ez volt azonban az első átfogó szakmai vita a regionális tervezés szerepéröl és eszközeiröl angolszász területen. A két oldal - az RPAA és a New Yorki tervezőcsoport - kiindulópontja azonban megegyezett abban, hogy a növekvő nagyvárosok gondjaira, terjeszkedésük ellenőrzésére, irányítására kerestek megoldásokat, és a felhasznált eszközök, módszerek is a várostervezés kelléktárából kerültek ki.

Az európai nagyvárosok közül elsőként London számára készült a várost és annak tágabb környékét is magában foglaló terv. A minták és a képzett szakemberek $R$. Unwin, L. P. Abercrombie személyében készen álltak. Az 1920-as, 30-as években készültek tervek a város terjeszkedésének korlátozására a beépitett területek zöldövezettel történő lezárásával és szatellit-városok tervezésével. A törvények azonban nem tették lehetövé ezeknek a lépéseknek az összehangolását egyetlen regionális terv keretei között. Az egyetlen kísérlet erre, a Nagy-London Regionális Tervezési Tanács (1927-1933) 45 helyi kormányzat képviselöit tömörítette a föváros 40 kilométeres körzetén belül. Unwin elképzelései szerint a London környéki beépitetlen területek tervezése és a terv végrehajtása egyetlen hatóság kezébe került volna. A kísérlet megbukott törvényi (és politikai) támogatás hiján, amiben nem kis része volt a tervezök (elsösorban $R$. Unwin) által javasolt, az építési befektetök érdekeit sértő beépítési korlátozásoknak. Geddes és az RPAA radikális elképzeléseinek megvalósítása a városi és regionális fejlődés tervezésére vonatkozóan tehát nem valósulhatott meg. (Cherry 1974) 
Nagy-London regionális rendezési terve végül a városból kiindulva született meg. A radikálisok idealizmusát félretéve, Abercrombie elkészitette London megye ${ }^{5}$ tervét, amely Nagy-Londonnál jóval kisebb területet foglalt magában és nem számolt a létező térbeli struktúrák drasztikus átalakitásával. A terv tartalmazta a pusztuló belsô lakó- és ipari negyedek megújitását, a zöld területek bỏvitését és az úthálózat átalakítását. Az utóbbi lépések új térszerkezet kialakitásának eszközei voltak: az új, hierarchikus úthálózat ${ }^{6}$ (körutak és sugárutak, illetve mellékutcák rendszere), a parkok és zöld sávok segítségével sejtszerū városszerkezetet tervezett, amelyben a beépítés sürüsége cellánként változó volt. $\mathrm{A}$ külső körgyürün, a beépített terület határán túl szatellit-városok épitését tervezték, amelyek a rurális térségben szigetszerü urbanizációs szigetek voltak.

A tervezés tehát szükségszerüen túllépett London megye határain 1944-ben, Abercrombie Nagy-London számára készült tervével. Az eredeti, kisebb terület számára készült vázlat elég rugalmasnak bizonyult ahhoz, hogy az utak és zöld területek gondos megtervezése révén a város terjeszkedése ne a környezö zöld területek pusztításával, hanem többé-kevésbé irányítottan és harmonikusan történjen. A terv évtizedekre meghatározta a londoni régió térbeli fejlödésének fö irányait, mert figyelembe vette a természeti környezet megóvásának szükségességét, lehetővé tette helyi közösségek kialakulását és számolt a politikai-gazdasági körülményekkel a tervezési folyamatban. (Hall 1985, 1993; Foley 1963)

\section{Növekedés és dekoncentráció: tervezés az ötvenes, hatvanas években}

A második világháború után fôlerősődő dekoncentrációs folyamatot a gazdaság és a jövedelmek növekedése, illetve a személygépkocsi-állomány gyors bővülése ösztönözte. A város- és regionális tervezés célja az ötvenes, hatvanas években a dekoncentrációs folyamat keretek között tartása, irányitása volt oly módon, hogy megörizzék az eredeti, koncetrált városi térszerkezetet. Ennek legfontosabb eszközei a zöldövezet (green belt) tervezése a már megépült elövárosok körül, amelyre szigorú épitési tilalmat rendeltek el; továbbá az 1947-es Város- és Vidékfejlesztési Törvény által támogatott átépítési (slum clearance) programok, amelyek célja a belsö, slumosodó lakóterületek újjáépítése volt. Ezzel igyekeztek megörizni a városok társadalmi és gazdasági egyensúlyát, illetve a lehető legkisebbre csökkenteni a városok által elfoglalt falusi területek nagyságát. Az utóbbi célt sikerült elérni: az észak-amerikainál tömörebb városszerkezetet sikerült megörizni és a környezet minőségét megóvni az urbanizáció káros hatásaitól. Az elövárosok növekedését azonban nem állíthatták meg. A folyamat megalkuvásra kényszerítette a brit városlakókat: vagy vállalták a hosszú, napi ingázás terheit, és a környező falvakban kerestek lakóhelyet, vagy megelégedtek a szükösebb, ám a korlátozások miatt gyorsan dráguló városi ingatlanokkal. A tervezök két alternatívát kínáltak: a többnyire városperemeken épülö, állami támogatást élvező ơnkormányzati lakásokat (tőbbnyire ötemeletes, vagy magasabb tömbházakban) és az új városokat.

A legnagyobb nyomás a nagyvárosok ingatlanpiacaira nehezedett a második világháború után. Ennek feloldására, az új városokról szóló törvény (New Towns Act, 1946) elfogadása után megkezdődött a szatellit-városok épitése London, illetve 
a nagy ipari centrumok (elsősorban Liverpool, Manchester és Glasgow) környékén. A programok tehát a városi fejlödés problémáit regionális szinten kezelték. Maga a fejlesztés állami támogatással, bürokratikus fejlesztési szervezetek irányitásával történt, amelyek jól-rosszul együttmüködtek az „anyavárosokkal” az 1952-es Városfejlesztési Törvény értelmében. Ez utóbbi csak London esetében volt harmonikusnak nevezhetö, a vidéki nagyvárosok általában tartottak adóbázisuk meggyengülésétöl, és kifejezetten ellenségesen viselkedtek az új településekkel szemben. (Carter 1984)

A fejlesztési szervezetek felállitásával sikerült elkerülni a nehézségeket, amelyek a helyi kormányzatok együttmüködéséböl (vagy annak hiányából) következhettek, és az intézmények megfeleltek a munkáspárti kormány centralizáló-bürokratikus irányítási stílusának is az 1940-es években. Az állami ellenörzés kiterjesztése érvényesült a városok gazdasági bázisának megóvása érdekében is. Az 1947-es Város- és Vidékfejlesztési Törvény értelmében közvetlen kormányzati kontroll érvényesült a jelentősebb ipari beruházások esetében, amely a nyolcvanas évek elejéig, a város és regionális tervezési politikában bekövetkezett tory fordulatig fennmaradt. (Horváth 1987) Bár az ötvenes éveket a brit szerzök a város- és regionális tervezés szempontjából is stagnáló szakasznak tekintik, az új városok építése folytatódott és nagyszabású infrastruktúra (elsősorban autópálya-épitési) programok indultak az évtizedben. (Smigielski 1971; Hall 1993)

Az 1950-es, 1960-as években beértek az új szatellit városokba fektetett szellemi és pénzügyi eröfeszítések. A településeken az eredeti, Howard-i, Geddes-i elképzelések közül sikerült megvalósitani a városi és természeti környezet harmóniáját a laza, kertvárosi jellegü beépítéssel; továbbá a kellemes és konfliktusmentes lakókörnyezetet. E települések gazdasági bázisa viszonylag szilárd volt az idetelepült szolgáltatásoknak és környezetbarát ipari tevékenységeknek köszönhetően, amelyek többnyire a szomszédos nagyvárosból települtek „ki” (különösen jellemzö volt ez London és bolygóvárosai esetében). Nyilvánvalóvá vált azonban, hogy a településhatáron túl nyúló tervek sem oldják meg a városi társadalom és környezet gondjait, és a decentralizációs folyamat vesztesei a város hagyományos, belső lakónegyedeiben és a gyengébb minöségü, önkormányzati tulajdonú lakótömbökben élök. Ök a városi környezeti problémák mellett a városi (és regionális) gazdasági bázis gyengülését is különösen megszenvedték.

A hatvanas években az újra „felszálló ágba” kerülö várostervezés a kis léptékü, értékmegőrzésre és felújitásra koncentráló városi programokkal reagált, amelyekben gyakran alkalmazták specializált övezetek (precincts) kialakitását, kirekesztve az autóforgalmat az adott területéről. Ezeknek a rendezési terveknek a célja továbbra is a város hagyományos struktúrájának megörzése, a szuburbanizáció térbeli kereteinek korlátozása volt.

A városi gazdaság megújitása azonban nem volt többé elképzelhetö helyi, illetve városkörnyéki fejlesztési tervek keretei között. Az ipari és szolgáltató tevékenységek dekoncentrációja, amely a hatvanas évek autópálya-építkezései következtében felgyorsult, továbbá a hagyományos ipari struktúrával rendelkező területek gondjai a munkáspárti politikusokat a regionális tervezés rendszerének kiépítésére ösztönözték. A hatvanas évek közepén kialakított régiókból, a megyékből és a településekből felépülő tervezési hierarchiát az ún. strukturális 
tervek (structure plans) foglalták keretbe, amelyek kidolgozásáról az 1968-as Város- és Vidékfejlesztési Törvény rendelkezett. Minden tervezési hatáskörrel felruházott (regionális, megyei és nagyvárosi) hatóság köteles volt ilyen hosszú távú tervet késziteni, amely regionális szinten általános ajánlásokat és alapelveket határozott meg a gazdaság és a közlekedési hálózat térbeli fejlődésére vonatkozóan. Ezek a tervek jelentették a kapcsolatot a nemzeti szintü, a regionális és a helyi tervezés között. Ezek voltak hivatottak kijelölni a kormányzati beavatkozás területeit is a következö 10 éves idöszakra. A tervet a környezeti ügyekért felelös miniszter hagyta jóvá, aki egyben felelös volt koordinációért is a stratégia megvalósítása során.

A tervek tehát egy-egy térség egészét érintő kérdések átfogó kezeléséhez biztosította a kereteket. Így volt ez például a kereskedelmi hálózat fejlesztése esetében. Ennek megtervezése egy, a helyi üzletektöl a regionális vonzású bevásárló központokig terjedő hierarchiát érintett. A városi népesség dekoncentrációja következtében egyre gyarapodó, nagy alapterületü, városszéli beruházások hatása egy-egy régió kereskedelmi hálózatának egészére kiterjedt. A hierarchizált területi és településtervezés lehetővé tette az új elemek lehetö legkevesebb feszültséggel (üzletek bezárása a hagyományos kiskereskedelmi centrumokban és alcentrumokban) történő megjelenését, beiktatását a rendszerbe. Mivel a városok elérhetösége jelentösen javult az évtizedben, egy-egy település kereskedelmi ellátása regionális rendszer keretei között történt. Ezért az új beruházás helyének kijelölésekor számba vették a potenciális vonzásterület népességének várható keresletét, növekedését és a rendelkezésre álló kapacitásokat nem csupán a közvetlenül érintett településeken, hanem a szomszédos városok kiskereskedelmi tömörülési esetében is.

$\mathrm{Az}$ urbanizációs folyamat ugyan már évtizedekkel korában túllépett a városok határain, de tervezésének, intézményes irányitásának, befolyásolásának feltételei csak a második világháború után alakultak ki. A folyamatot ösztönözte a népesség, az ipar és a szolgáltató tevékenységek gyorsuló dekoncentrációja, a munkáspárti politikusok neki-nekilendülö törekvései a regionális egyenlötlenségek csökkentésére és az általános igény a várostervezők és politikusok körében az urbanizációs trendek bizonyos keretek között tartására. A város- és regionális tervezés hatvanas években kialakitott közös kereteit, amelyeket a növekvő városi gazdaságra és népességre szabtak, már a következö évtizedben támadások érték, amelyek bevezették a tervezés történetének újabb, defenziv korszakát.

\section{Visszavonulás}

A hetvenes években alapvetöen megváltoztak a tervezéssel kapcsolatos elvárások: véget ért a gazdaság hosszú, növekedéssel jellemezhetö korszaka, és felszínre kerültek a brit gazdaság szerkezeti gyengeségei. (White 1988) A kormányzati beavatkozás elsődleges céljává a hanyatló területek megújitása, a gazdasági növekedés serkentése vált. A hetvenes évtized a habozás, a bizonytalanság korszaka volt a területi- és várostervezésben is. Felmérték a válság fizikai jeleit - elhagyott ipari, kereskedelmi területek növekvő mennyisége, hasznosítatlan városi telkek megjelenése a gazdasági tevékenység hagyományos színhelyein - hátterében álló 
tényezőket, amelyek a városi gazdaság meggyengülésére, söt válságára utaltak. $\mathrm{A}$ legfontosabb cél tehát a gazdasági bázis erősítése volt, elsősorban ipartelepítés révén.

A munkáspárti kormány által a hetvenes évek közepén támogatott programok azonban nem vették figyelembe a gazdaságban ekkor már jól látható strukturális átalakulás jeleit, elsősorban az ipar térvesztését a szolgáltató szektor javára, amely pedig a város és regionális szintü területi különbségekre is magyarázattal szolgált. Jó példa erre a munkáspárti Nagy-London Tanács által támogatott program a londoni kikötő (the Docklands) megújítására. A területröl az ipari és nagykereskedelmi tevékenysége mellett az állami nagy szolgáltatók (British Rail, British Gas) is kivonultak. Az ingatlanokat ipari, nagykereskedelmi, raktározási és (olcsó) lakófunkció ellátására tervezték. A piaci igényeket figyelmen kívül hagyva, csekély teret hagytak a szolgáltató tevékenységeknek, elsősorban az irodáknak. A szükülő fejlesztési források ennek a változatnak a végrehajtását meghiúsították. ${ }^{7}$

A munkáspárti politikusok tehát újraelosztó szerepet szántak a tervezőknek, akik feltárták a szükséges beavatkozási területeket, és el is költötték az adófizetök pénzét. Ezzel a konzervatív politikusok és a lakosság többsége számára támadhatóvá váltak, ami a nyolcvanas években a regionális és várostervezés intézményeinek és hatáskörének megkurtításảhoz, továbbá a tervező szakemberek jelentős részének elbocsátásához vezetett. Mindezt a tervezés növekvő átpolitizálódása következményének tekinti a legtöbb brit szerzõ. (Harrison 1982; Hall 1993)

Az 1979-ben kormányt alakító konzervatívok a tervezés szerepét az ingatlanok lehető leghatékonyabb hasznosításában jelölték meg. Az 1983-as Fehér Könyv ${ }^{8}$ elvetette a stratégiai tervezés szükségességét, a területhasznositási problémák eseti kezelését jelölte meg a tervezők feladatául. Ezzel párhuzamosan megkezdődött a tervezési a tervezési jogkörrel rendelkező hatóságok megszüntetése, illetve hatáskörük korlátozása. Az 1980-as tervezési törvény a megyék ilyen jellegü jogköreit nagyobbrészt alacsonyabb igazgatási szinthez, a kerületekhez (districts) rendelte, majd 1986-ban a megyék teljesen elvesztették szerepüket a tervezésben. Ezzel párhuzamosan megszünt a Nagy-London Tanács és nyolc másik, vidéki városrégió igazgatási-tervezési hatósága is."

A tervezés eseti beavatkozásai a nyolcvanas években a belső lakóterületek és a belvárosok folyamatosan zajló megújítási programjai mellett az ún. vállalkozói zónák (Enterprise Zone) voltak. Utóbbiak megtestesítették a neoliberális kormányzati politika alapelveit. Létrejöttük célja a városi gazdaság megújítása volt kormányzati beavatkozással. A magánbefektetők beruházásai a remények szerint a befektetett közpénzeken többszörösét tették volna ki. Az utóbbiak számára a zónák kedvező adózási feltételeket, lazább épitési szabályokat és garantáltan gyors ügyintézést kínáltak, és természetesen viszonylag olcsó városi ingatlanokat, hiszen minden esetben elhagyott, üres telkekröl volt szó. A londoni kikötő újrahasznosítása a programok közül a legismertebb, amely a terület fizikai megújítása mellett az itt koncentrálódó szerepkörök átalakítását eredményezte a kiterjedt irodaház- és (igen drága) lakóház-építkezésekkel. A közel 300 millió fontnyi állami beruházást annál hatszor nagyobb tömegủ magánbefektetés követte. 
A zónák sikere, vagy sikertelensége a tory gazdaságpolitika eredményein túl a kormányzat területi tervezéssel kapcsolatos magatartásának kritikája is. A Docklands megújulása akár sikerként is elkönyvelhető, hiszen egy városrész fejlődésnek indult és új munkahelyeket teremtettek. Az ehhez hasonló övezetek létrehozását mégis bírálják, mert nem oldják meg azokat a társadalmi feszültségeket, amelyek a régi (ipari, szállitási stb.) funkciók megszünésével keletkeztek. Az innen elköltözök sem találnak lakást a megújult, ezért megdrágult területen. A fejlesztési területek kijelölésének ugyanakkor nincsenek tervszerü keretei, a városi gazdaság válságának eseti kezelése pedig egyelöre nem hozott látványos javulást. (Hall 1985, 1993) Ráadásul az egyedi fejlesztési tervek elbírálása a bürokratikus minisztériumi hivatalokban történik, ami egyrészt hosszadalmas folyamat, másrészt többnyire távol van magától a beavatkozási területtöl.

A tervezés új, konzervatív definíciója önmagában tehát nem vezetett sem a városok gazdasági bázisának számottevő erősödéséhez, sem az azokkal összefüggő társadalmi feszültségek (szegénység, bevándorlók helyzete, pályakezdö munkanélküliség, illetve e jelenségek koncentrációja a pusztuló belső lakóterületeken) enyhítéséhez. Ugyanakkor továbbra létezik az igény a (helyi és központi) kormányzati beavatkozásra az említett konfliktusok kezelésére, illetve távol tartására a társadalom nyugalmat és elkülönülést kedvelö többsége, a középosztály, továbbá maguknak a társadalmi ranglétrán lecsúszó csoportjai részéröl.

\section{Jegyzetek}

${ }^{1} \mathrm{Az}$ amerikai tervezés, európaiakat megragadó vivmánya a természeti környezet védelme (nemzeti parkok), illetve a városszépités eredményei, amelyet nagy teruletủ parkok kialakitásával értek el (mint például a F. Olmstead tervezte Central Park New Yorkban).

${ }^{2}$ Geddes skót volt.

${ }^{3}$ A szerző forditása.

${ }^{4}$ Geddes, P. 1915: Cities in Evolution. London: Williams and Norgate

${ }^{5}$ A kőzigazgatási egység (London megye, London County) és az azt irányitó, demokratikusan választott testület (London County Council, LCC) 1888-tól létezett, és rendelkezett tervezési-rendezési hatáskőrrel.

${ }^{6}$ A hálózat megtervezése Alker Tripp, a Scotland Yard kőzlekedési felügyelọjének nevéhez füzödik, aki a modern, növekvő személygépkocsi forgalmat átereszteni képes, hierarchizált úthálózat koncepcióját kidolgozta (1938).

${ }^{7}$ A projekt a becslések szerint folyó áron 900 millió brit fontba került volna 1974-ben.

${ }^{8}$ G.B. Department of the Environment, 1983

${ }^{9}$ G.B. Department of the Environment, 1986.

\section{Irodalom}

Cherry G. E. (1974) The Evolution of British Town Planning. London: Leonard Hill

Geddes, P. (1915) Cities in Evolution. London. Williams and Norgate

Foley, D. L. (1963) Controlling London's Growth: Planning the Great Wen, 1940-1960.

Berkeley:University of California Press

Hall, P (1985) The People: Where will they go? Planner, 71.4. 3-12.

Hall, P. (1993) Cities of Tomorrow. Longman, London

Hall, P.- Hass-Klau, M. (1983) Can rail save the city? 
Harrison, B. (1982) The Politics and Economics of Urban Enterprise Zone. A Critique. International Journal of urban and Regional Research, 6, 422-428

Hass-Klau, M. (1988) The pedestrian in the city in Britain and Germany. Oxford Press, London-Berlin, pp. 122-251

Healy, P. (1991) Urban Regeneration and the Developemnt Industry. Ekistiks, 349, pp. 83-98.

Horváth Gy. (1997) Fejlettségi különbségek és fejlesztési politikák az Egyesült Királyságban és Irországban. In: Régiók felemlkedése és hanyatlása. MTA RKK, Pécs, pp. 17-97.

Howard, E. 1898. To-morrow: a Peaceful Path to a Real Reform. London: Swan Sonnenschein

Improving inner city shopping centres. Public Sector Management Research centre, Aston University, 1989

Lawlets P. (1989) Britain's Inner Cities Longman, London

Matthews H. (1995) British Inner Cities. Oxford University Press: Oxford

Parker, A. J. (1975) Hypermarkets: the Changing Pattern of Retailing. Geography, 60. pp. 120-134.

Mumford, L. (1938) The culture of Cities. Lonodn: Secker and Wartburg

Policy for the Inner City. Structure and Processes. Centre for Mass Communication, Univ. of Leicester, 1983

Potter, R. B. (1982) The Urban Retailing System: Location, Cognition and Behaviour. Aldershot, Gower. Pp. 71-183.

Robertson K. (1994) Pedestrian Malls and Skywalks. Aldershot, Avebury Press

Street Program as a Community Economic Developemnt Tool. Urban Design and Preservation Quarterly 15, pp. 51-55

Smigielski F. (1971) Draft for the 1971 Structure Plan for the City of Leicester. Leicester City Council Sutcliffe A. (1981) Towards the Planned City. Blackwell, Oxford

White P. (1988) The West European City. A Social Geography. Longman: London and New York. pp. $134-151,191-212$

\section{Források}

Census of Population, 1961 General Register Office, 1962

Census of Population, 1981. General Register Office, 1984.

Postcode Census Monitor, Office of Population Census and Surveys, 1994

Improving inner city shopping centres. Inner City Research Program. Department of Environment, 1986

The Future of the High Street. Distributive Trades EDC, London, 1988

Assessing the Impact of Urban Policy. Department of the Environment Inner Cities Research

Programme. London, HMSO, 1994

The Leicester City Shopping Survey, 1995 Leicester City Council

Leicester City Development Plan. Written Analysis . Leicester, Town Hall, 1952

City of Leicester Local Planning Background papers. Leicester City council, November, 1992

City Centre Action Programme Review. Second Draft, June 1995. Leicester City Council 